\title{
Response of Mature 'Manzanilla' Olive Trees to Different Doses of N-P- K Fertilizer Applied by Fertigation
}

\author{
A. Morales-Sillero \\ Dpto. de Ciencias Agroforestales, \\ Universidad de Sevilla \\ Ctra. de Utrera, km 1, 41012 \\ Sevilla, Spain
}

J.E. Fernández and A. Troncoso

Instituto de Recursos Naturales y Agrobiología,

(CSIC). Apartado 1052, 41080 Sevilla, Spain.

KEYWORDS: Olea europaea L., olive nutrition, table olive quality, olive oil quality.

\begin{abstract}
Fertigation is widely used in the new intensive olive orchards, although, there is not enough information for a rational management of this practice. Preliminary results of an fertigation experiment iniciated in 1999 in a mature olive orchard of the cultivar 'Manzanilla de Sevilla' are presented. Four treatments were established: T1(no fertilizer) and T2, T3 and T4, in which the trees received 200, 400 and $600 \mathrm{~g} \mathrm{~N}$ per tree and irrigation season (May to October), respectively, of a dose of a complex 4:1:3 N-P-K fertilizer applied by fertigation. The water used for irrigating the orchard had a nitrate content equivalent to $60 \mathrm{~g} \mathrm{~N}$ per tree, aproximately. Vegetative growth, yield and some variables related to table olive and oil quality were measured in all the treatments. No significant differences between treatments were found on shoot length and yield. Some physical properties, such as mean fruit weight, flesh/stone ratio and volume, increased with the amount of fertilizer applied, while texture and reducing sugars decreased, affecting table olive quality. Oil quality was affected negatively by fertigation since polyphenol content, bitterness, stability and monounsaturated fatty acids decreased when the amount of fertilizer increased. The polyunsaturated fatty acids, however, increased when increasing the fertilizer amount.
\end{abstract}

\section{INTRODUCTION}

In Spain, approximately $19 \%$ of the olive cultivated area is grown under irrigation. Most of the orchards use high frecuency irrigation and fertigation . Despite this, just a few works have been published on the matter. Troncoso et al. (1997) observed, after eight years of $2 \mathrm{~kg}$ of urea $(46 \%)$ per tree fertigation, an increase on vegetative growth and yield in 25-years-old 'Manzanilla de Sevilla' trees, while fruit weight was not affected. No response was found by Alcubilla et al. (2004) in young trees of 'Arbequina' and 'Empeltre' after four years of different doses of $\mathrm{N}$ applied by fertigation. In other fruit tree species, fertigation increased the yield when compared with traditional broadcast application (Boman, 1996; Alva and Paramasivan, 1998) and no yield reduction was observed when reduced $\mathrm{N}$ amounts were applied by fertigation instead than by broadcast application. (Smith; 1979; Kipp, 1992). On the other hand, an excess of N fertilizer can negatively affect fruit quality, independently of the application method (Dasberg et al. 1983, He et al., 2003).

The aim of this work was to study the effect on vegetative growth, yield, and fruit and oil quality, of different doses of an N-P-K fertilizer applied by fertigation in a mature 'Manzanilla de Sevilla' olive orchard. 


\section{MATERIALS AND METHODS}

\section{Experimental details.}

The trees were 10 years old in 1999, when the experiments began. They belong to an orchard planted at $7 \mathrm{~m} \times 7 \mathrm{~m}$, located near Alcalá de Guadaíra, at $15 \mathrm{~km}$ of Seville (southwest Spain). Four treatments were established: a control treatment (T1), in which the trees were irrigated but not fertilized, and three fertigation treatments, in which the trees received a dose of a complex 4:1:3 N-P-K fertilizer equivalent to 200 (T2), 400 (T3)and 600 (T4) g N per tree and irrigation season (May to October). Each tree received an additional dose of approximately $60 \mathrm{~g} \mathrm{~N}$ per tree due to nitrate content in the water used for irrigation. A randomised block design (six blocks per treatment, four trees each) was used to test the effect of the treatments. The trees were irrigated daily, with a localised irrigation system. Enough water was supplied to replace the crop evapotranspiration calculated as $\mathrm{ET}_{\mathrm{c}}=K_{c} K_{r} \mathrm{ET}_{\mathrm{o}}$, being $\mathrm{ET}_{\mathrm{o}}$ the potential evapotranspiration in the area, determined with the FAO56 Penman-Monteith equation (Allen, 1998) from the data registered by an automatic weather station next to the orchard. The $K_{r}$ and $K_{c}$ coefficients were previously adjusted for the orchard conditions by Fernández (2003). In the fertigated treatments the fertiliser was supplied daily. Data from 2003 to 2004 are shown in this study.

\section{Shoot growth and yield}

Shoot length was measured at the end of the growing season in 10 previously tagged (fructíferos shoots per tree. Flowering quantity was estimated in full bloom, according to four visual classes, from 1 (very low) to 4 (very high). The yield per tree was evaluated in September, once the fruits had reached the maturity index 1, determined according to Uceda and Hermoso (2001).

\section{Fruit and oil quality}

Different fruit samples were collected to evaluate some variables related to physical characteristics: mean fresh weight, flesh/stone ratio, volume and texture. The fruit texture was measured using an Instron texturometer fitted with a Kramer shear-press cell. A sample of $3 \mathrm{~kg}$ per block was taken to determine reducing sugars, water and oil content, and oil quality. Reducing sugars content was also calculated according to Lane Eynon method, following the Official Methods of the AOAC (1995). Water content was calculated by desiccation at $105^{\circ} \mathrm{C}$ of a milled fruit sample. Oil content was determined by nuclear magnetic resonance (NMR). Oil was extracted by an Abencor analyzer. Acidity, peroxide number, $K_{232}, K_{270}$ and fatty acid composition were measured according to EU Regulations 2568/91. Polyphenols and tocopherols contents were measured by colorimetry (Vázquez et al. 1973) and the IUPAC (1992) method, respectively. Bitterness $\left(K_{225}\right)$ was determined by absorbance at $225 \mathrm{~nm}$ (Gutiérrez et al.,1992) and oil stability by using a Rancimat apparatus according to Gutiérrez et al. (1989).

Differences between treatments were tested by doing the analysis of variance and regressions analyses. Just the yield was analyzed by covariance using the canopy volume covariate. 


\section{RESULTS AND DISCUSSION}

No differences neither on shoot growth (147 mm of mean value) nor on yield $(6,52 \mathrm{~kg}$ per tree mean value) were found between treatments. A severe attack of leaf spot (Spilocaea oleagina (Cast.) Hughes) happened in the spring of 2003, which caused a marked shoots defoliation, likely affecting fruit set and reducing yield. Flowering showed a general tendency to increase with the amount of fertilizer applied, ranging from 1.3 for T1 to 2.3 for T4. The same tendency was observed in the spring of 2004, with the flowering index ranging from 2.0 for $\mathrm{T} 1$ and 3.1 for $\mathrm{T} 4$. A positive correlation was observed by Ramírez-Santa Pau et al. (2002) between flowering quantity and yield in 20years-old trees of the same cultivar.

Some physical properties of the fruits, such as mean fresh weight, flesh/stone ratio and volume, significantly differed among treatments (Table 1). These variables showed a lineal tendency to increase with the applied doses. However, texture, a very important quality attribute affecting the number of broken fruits in industrial operations, showed a negative tendency. This was due probably to the fruit water content, which was higher for the higher fertilizer treatments. The correlations between texture and water content was 0.762. Oil content was not affected by fertigation, but the content in reducing sugars, the main carbon sources for fermentation process, were lower in the two higher fertilizer treatments.

Table 2 indicates the results of the oil samples analysis. For the two lower fertilizer treatments, oils samples had high pigments levels and could not be passed through alumina. These were the reasons by which the ultraviolet coefficient of extintion $K_{270}$ showed mean values above the maximun tolerated $(0.20)$. Therefore, it could be considereted, from an analytical point of view, that all the examined oils samples fall into the extra virgin category.

The fertigation treatments also affected some oil quality parameters. Polyphenols content, related to oxidative stability and bitterness, significantly decreased for T3 and T4. Fernández-Escobar et al. (2002) observed, in mature 'Picual' trees, that the broadcast application of $1 \mathrm{~kg} \mathrm{~N}$ per tree negatively affected polyphenol content. On the other hand, an excess or deficiency of $\mathrm{N}$ can produce, in other species, imbalance between polyphenols synthesis and another organic compounds, like sugars and free aminoacids (Alcubilla et al. 2004) The peroxide number and ultraviolet coefficients of extintion $K_{232}$ and $K_{270}$ showed lower values for the higher doses of fertilizer. However, this was due probably to the oil extraction process and not to the fertigation treatments.

Some fatty acids were also significatively affected (Table 3). In general, the monounsaturated acids, beneficials to the health, decreased with the amount of fertilizer applied. The contrary was observed for the polyunsaturated acids, which are the fatty acids more reactive to oxidation process. Saturated fatty acids were no affected by fertigation. Simões et al.(2002) observed, in a 'Carrasquenha' olive orchard, that high levels of $\mathrm{N}$ broadcast fertilization had a negative influence in the saturated fatty acids. No effects were found in mono and polyunsaturated fatty acids.

In conclusion, some physical fruit properties, such as mean fresh weight, flesh/stone ratio and volume were positively affected by the fertigation treatments, while texture and reducing sugar content, were negatively affected. Fertigation also affected negatively some oil characteristics, such as polyphenol content, bitterness, stability and fatty acid composition. 


\section{ACKNOWLEDGEMENTS}

This research was supported by the Programa de Mejora de la Calidad de la Producción del Aceite de Oliva (Olive Oil Quality Improvement)-CAO 98-004. We wish to extend our gratitud to from Experimental Station "Venta del Llano" of Junta de Andalucía and Institut de la Grasa (C.S.I.C) for their kind collaboration.

\section{CITATIONS AND LITERATURE CITED}

Alcubilla , M., Romero, M.A., Broca, A., Negueruela, A.I., Monge, E., Val, J., Espada, J.L., Betran J. and Gracia, M.S. 2004. Contribución al estudio de las variedades de olivo Empeltre y Arbequina de Aragón. In: Difusión de los Resultados de Investigación del Programa de Mejora de la Calidad dela Producción del Aceite de Oliva. III Jornadas Técnicas del aceite de oliva. INIA. Pp.: 157-168.

Allen, R., Pereira, L.S., Raes, D. and Smith, M. 1998. Crop evapotranspiration Guidelines for computing crop water requirements- FAO irrigation and drainage paper 56, FAO, Rome. http://www.fao.org/docrep/X0490E/X0490E00.htm

Alva, A.K. and Paramasivan, S.1998. Nitrogen management for high yield and quality of Citrus in sandy soils. Soil Science Society of. America Journal. 62: 1335-1342.

Boman, B.J. 1996. Fertigation versus conventional fertilization of flatwoods grapefruit. Fertilizer Research 44: 123-128.

Dasberg, S., Bielorai, H. and Erner, J. 1983. Nitrogen fertigation in Shamouti oranges. Plant and Soil 75: 41-49.

Fernández, J.E. 2003. Riego del olivar de mesa y de almazara. In: Tecnologías del Agua en Zonas Agrícolas y Verdes. Paneque, G. (ed.) Department of Chemical Agriculture, University of Seville, $18 \mathrm{pp}$.

Fernández-Escobar, R., Sánchez-Zamora, M.A., Uceda, M. and Beltrán, G. 2002. The effect of nitrogen overfetilization on olive tree growth and oil quality. Acta Horticulturae 586: 429-431.

Gutiérrez, F., Albi, M.A., Palma, R., Ríos, J.L. and Olías, J.M. 1989. Bitter taste and virgin olive oil: correlation of sensory evaluation and instrumental HPLC analysis. Journal of Food Science 54: 68-70.

Gutiérrez F., Perdiguero, S., Gutiérrez, R. and Olias, J.M. 1992. Evaluation of the bitter taste in virgin olive oil. Journal of The American Oil Chemists Society 69: 394-395.

IUPAC. 1992. Standard method for the analysis of oils, fats and derivatives. Method 2432. Pergamont Press, Oxford.

Kipp, J.A. 1992. Thirty years fertilization and irrigation in Dutch apple orchards. Fertilizer Research 32: 149-156.

Simões, P., Pinheiro-Alves, C., Cordeiro, A.M. and Marcelo, M.E. 2002. Effect of the nitrogen and potassium fertilization on fatty acids composition and oxidative stability for 'Carrasquenha' cultivar olive oil at different harvest periods-preliminary study. Acta Horticulturae 586: 337-340.

Smith, M.W., Kenworthy, A.L. and Bedford, C.L. 1979. The response of fruit trees to injection of nitrogen through a trickle irrigation system. Journal of the American Society for Horticultural Science.104: 322-323.

Troncoso, A., Liñán, J., Cantos, M., Zárate, R. and Lavee, S. 1997. Influencia de la fertirrigación con urea sobre la disponibilidad de N-NO3 y el desarrollo del olivo. Fruticultura Profesional 88: 83-87. 
Uceda, M. and Hermoso,M. 2001. La calidad del aceite de oliva. In: El cultivo del olivo. Barranco, D., Fernández-Escobar, R. and Rallo, L. $4^{a}$ ed. Junta de Andalucía y Ed. Mundi-prensa, pp 589-614.

Vázquez, A., Janer, C. and Janer, M.L. 1973. Determinación de los polifenoles totales del aceite de oliva. Grasas y aceites 24: 350-357.

\section{Tables}

Table 1. Effect of the fertigation treatments on fruit quality. See text for details on treatments.

\begin{tabular}{|c|c|c|c|c|c|c|c|c|}
\hline Treatment & $\begin{array}{c}\text { Weight } \\
(\mathrm{g})\end{array}$ & $\begin{array}{c}\text { Flesh/stone } \\
\text { ratio }\end{array}$ & $\begin{array}{c}\text { Volume } \\
\text { (ml) }\end{array}$ & $\begin{array}{l}\text { eTexture } \\
\qquad(\mathrm{N} / \mathrm{g})\end{array}$ & $\begin{array}{c}\text { Water } \\
\text { content } \\
(\%)\end{array}$ & $\begin{array}{l}\text { Oil ce } \\
(\% \\
\text { f.w. })\end{array}$ & $\begin{array}{l}\text { ontent } \\
\qquad(\% \\
\text { d.w. }) \\
\end{array}$ & $\begin{array}{l}\text { Reducing sugar } \\
\text { content } \\
\text { (ppm d.w.) }\end{array}$ \\
\hline $\mathrm{T} 1$ & 4.25 & 5.11 & 4.02 & 99.02 & 58.73 & 13.26 & 32.13 & 105.451 \\
\hline $\mathrm{T} 2$ & 4.21 & 5.83 & 4.33 & 86.60 & 58.33 & 14.83 & 35.47 & 111.996 \\
\hline $\mathrm{T} 3$ & 4.81 & 6.42 & 4.75 & 77.16 & 62.44 & 13.45 & 35.72 & 89.118 \\
\hline $\mathrm{T} 4$ & 5.03 & 6.65 & 4.94 & 77.01 & 63.38 & 12.55 & 34.20 & 90.864 \\
\hline Significance & $\mathrm{L} * * *$ & $\mathrm{~L} * * * *$ & $\mathrm{~L} * * *$ & $\mathrm{~L}^{* *}$ & $\begin{array}{c}\mathrm{L}^{* * *} \\
\mathrm{C} *\end{array}$ & NS & NS & $\mathrm{L}^{*}$ \\
\hline
\end{tabular}

Table 2 Effect of the fertigation treatments on oil quality. See text for details on treatments.

\begin{tabular}{|c|c|c|c|c|c|c|c|c|}
\hline Treatment & $\begin{array}{l}\text { Acidity } \\
\text { (\% oleic } \\
\text { acid) }\end{array}$ & $\begin{array}{c}\text { Peroxide } \\
\text { number } \\
(\mathrm{meq} \\
\left.\mathrm{O}_{2} / \mathrm{Kg}\right)\end{array}$ & $\mathrm{K}_{232}$ & & $\begin{array}{l}\text { Polyphenol } \\
\text { content } \\
(\mathrm{ppm})\end{array}$ & Bitterness & $\begin{array}{c}\text { Tocopherol } \\
\text { content } \\
(\mathrm{ppm})\end{array}$ & $\begin{array}{c}\text { Stability } \\
\text { (h) }\end{array}$ \\
\hline $\mathrm{T} 1$ & 0.4 & 15.04 & 1.78 & 0.23 & 1272 & 0.54 & 304 & 154.32 \\
\hline $\mathrm{T} 2$ & 0.4 & 16.57 & 1.80 & 0.23 & 1281 & 0.53 & 270 & 147.68 \\
\hline $\mathrm{T} 3$ & 0.4 & 13.07 & 1.63 & 0.18 & 794 & 0.41 & 265 & 97.13 \\
\hline $\mathrm{T} 4$ & 0.3 & 11.76 & 1.70 & 0.18 & 860 & 0.48 & 269 & 103.02 \\
\hline Significance & NS & $\mathrm{L}^{* *}$ & $\begin{array}{l}\mathrm{L}^{*} \\
\mathrm{Q}^{*}\end{array}$ & $\begin{array}{l}\mathrm{L}^{* *} \\
\mathrm{C}^{*}\end{array}$ & $\begin{array}{l}\mathrm{L}^{* * *} \\
\mathrm{C}^{* *}\end{array}$ & $\begin{array}{l}\mathrm{C}^{* *} \\
\mathrm{~L}^{*}\end{array}$ & NS & $\begin{array}{l}\mathrm{L}^{* * *} \\
\mathrm{C}^{* *}\end{array}$ \\
\hline
\end{tabular}


Table 3. Effect of the fertigation treatments on the oil fatty acid composition (\%). See text for details on treatments.

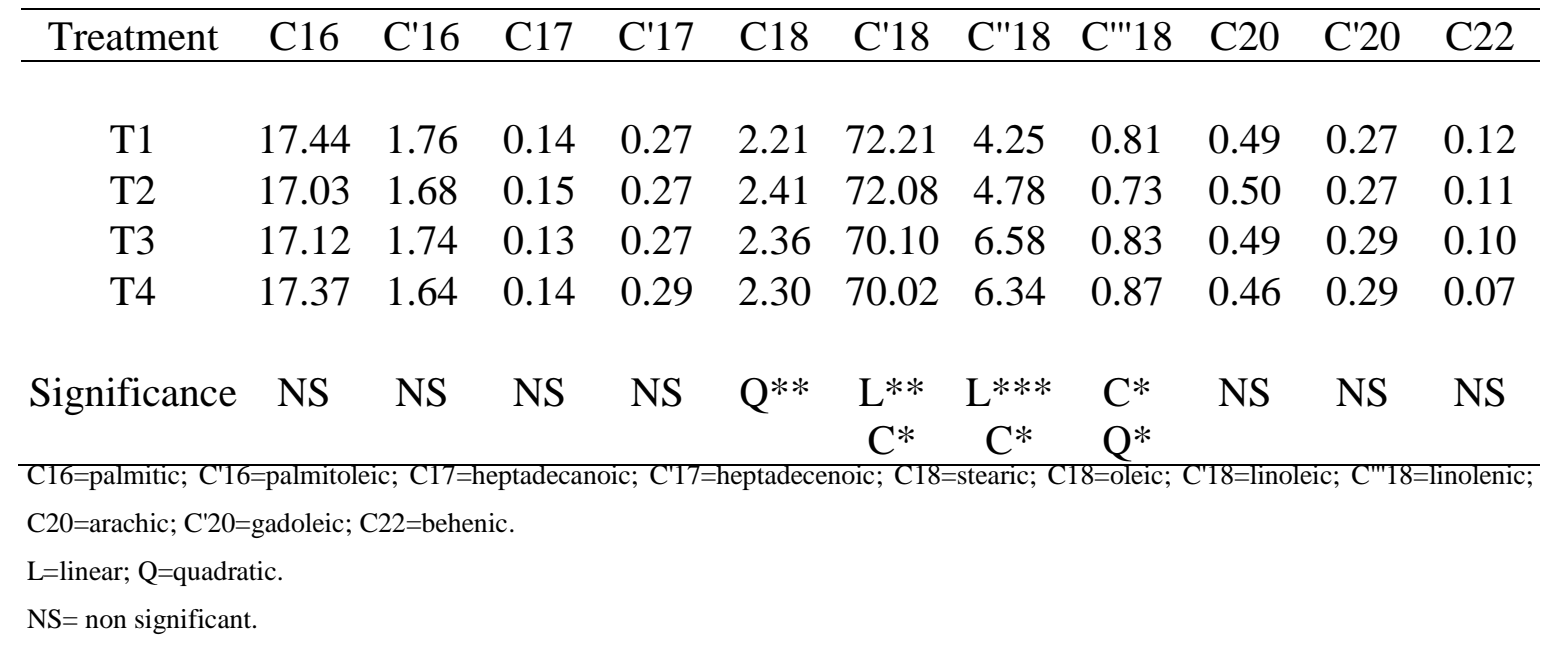

